\title{
Neuropeptide $Y$ receptor expression in human primary ovarian neoplasms
}

\author{
Meike Körner, Beatrice Waser and Jean Claude Reubi \\ Division of Cell Biology and Experimental Cancer Research, Institute of Pathology, University of Bern, Bern, \\ Switzerland
}

\begin{abstract}
Peptide hormone receptors overexpressed in human malignant neoplasms are potential targets for diagnostic scintigraphy and radiotherapy. One such receptor is the neuropeptide Y (NPY) receptor, mediating primarily feeding behavior in the brain but shown recently to play a role in breast cancer. In this study, the presence of NPY receptors was evaluated in another group of gynecological tumors, namely ovarian tumors, using in vitro receptor autoradiography with ${ }^{125}$-labeled peptide $Y Y$ and receptor subtype selective analogs. Remarkably, all 10 investigated inhibin-expressing granulosa cell tumors, Leydig cell tumors, and Sertoli-Leydig cell tumors expressed NPY receptors. In contrast, receptors were found in only seven of 22 ovarian adenocarcinomas (32\%). Pharmacological characterization of the expressed NPY receptor subtypes in the various tumors revealed the presence of $Y 1, Y 2$, or both. In addition, Y1 receptors were observed in intra- and peritumoral blood vessels as well. NPY receptors were not expressed in three ovarian adenomas, three borderline tumors, four fibromas and fibrothecomas, and one dysgerminoma. This is the first time that NPY receptors are described in human ovarian tissue. They may play a role in the pathogenesis and also in the pathophysiology of ovarian malignancies. Moreover, the high incidence and density of NPY receptors in sex cord-stromal tumors suggest that these receptors represent a new potential target for the diagnostic and therapeutic administration of NPY analogs in these tumors.
\end{abstract}

Laboratory Investigation (2004) 84, 71-80, advance online publication, 20 November 2003; doi:10.1038/labinvest. 3700009

Keywords: NPY receptor; receptor autoradiography; human ovary; tumor targeting; sex cord-stromal tumor; adenocarcinoma

Regulatory peptides are small, very potent molecules located mainly in the brain, gut, endocrine, and immune systems, with paracrine and neurocrine modes of action. In the last several years, it was shown that the receptors of these peptides are not only present in normal human tissue but are also overexpressed in a large variety of human neoplasms. ${ }^{1}$ This is of increasing clinical relevance since these receptors are potential targets for imaging and radiotherapy by radiolabeled peptide hormone analogs. ${ }^{2}$ For example, the use of the radiolabeled somatostatin analog Octreoscan ${ }^{\circledR}$ for diagnostic imaging of somatostatin receptor positive gastroenteropancreatic endocrine neoplasms is well established, ${ }^{3}$ and recent studies showed that targeted radiotherapy of these tumors with radiolabeled somatostatin analogs is successful. ${ }^{4}$ Also,

Correspondence: JC Reubi, MD, Division of Cell Biology and Experimental Cancer Research, Institute of Pathology, University of Bern, PO Box 62, Murtenstrasse 31, CH-3010 Bern, Switzerland. E-mail: reubi@pathology.unibe.ch

Received 06 March 2003; revised 07 August 2003; accepted 20 August 2003; published online 20 November 2003 the unlabeled somatostatin analog octreotide is routinely applied to control hormonal hypersecretion of a variety of somatostatin receptor-expressing neuroendocrine neoplasms. ${ }^{5}$

One regulatory peptide that may be worth studying in cancer is neuropeptide Y (NPY) ${ }^{6,7}$ It is part of the highly conserved NPY family consisting of NPY, peptide YY (PYY), and pancreatic polypeptide (PP). NPY, a 36 amino-acid long peptide characterized by a large number of tyrosine residues, is located mainly in the central and peripheral nervous system where it is a neurotransmitter. ${ }^{8}$ Among a large variety of regulative functions, it stimulates feeding and has a vasoconstrictive effect. ${ }^{9}$ Its role in reproduction at the level of the hypothalamichypophyseal axis by modulation of LHRH and LH secretion was extensively investigated in rodents, ${ }^{10-12}$ but is less clear in humans. The members of the NPY family display their actions via the various NPY receptor subtypes that belong to the G proteincoupled receptor superfamily. Five receptor subtypes are characterized by now. In humans, Y1, Y2, Y4, and Y5 are physiologically expressed, whereas Y6 has been demonstrated only at the mRNA level. 
A Y3 receptor subtype has not yet been proven to exist. $^{8}$

Up to now little is known of the role of NPY receptors in tumor biology. It was shown only recently that in human breast carcinomas, the incidence of NPY receptors was as high as $85 \% .{ }^{6,7}$ In these cases, the Y1 receptor predominated and was often expressed in high density and great homogeneity, whereas Y2 was present only focally in a small number of cases. Moreover, it was shown that NPY induced a dose-dependent inhibition of tumor cell growth of over $40 \%$ in a Y1-expressing human neuroblastoma cell line. ${ }^{6}$ This indicates that Y1 receptors may play a role in tumor cell proliferation and suggests a potential antiproliferative effect of NPY in Y1-expressing neoplasms. ${ }^{6}$

The aim of the present study was to investigate NPY receptor expression in tumor types other than breast cancer. Ovarian neoplasms were chosen because the ovary, like the mammary gland, plays a role in reproduction, and ovarian neoplasms, like breast carcinomas, undergo hormonal influences. Moreover, only few other peptide hormone receptors were reported to be expressed in a high percentage of ovarian tumors. ${ }^{13-15}$ Ovarian malignancies are a major problem in oncology. Adenocarcinomas are frequently diagnosed at an advanced stage with dissemination in the peritoneal cavity and beyond. Consequently, chemotherapy is often administered in these patients, and long-term prognosis is usually poor. ${ }^{16}$ Malignant sex cordstromal tumors are characterized by a very variable clinical course, and multiple and late recurrences occur. ${ }^{17}$ Therefore, new diagnostic and treatment strategies for ovarian malignancies are of considerable interest.

\section{Materials and methods}

\section{Tissues}

\section{Human specimens}

Fresh frozen tissue samples obtained from ovarian surgical specimens of 45 patients were included in the study. The diagnosis of the 43 investigated primary or recurrent ovarian neoplasms was reviewed and formulated according to the WHO guidelines $^{18}$ using hematoxylin and eosin (HE)stained $10 \mu \mathrm{m}$ cryostat sections. The material comprised 28 surface epithelial-stromal tumors including three adenomas (one serous, two mucinous), three borderline tumors (all mucinous), and 22 adenocarcinomas (15 serous, five endometrioid, two mucinous); 14 sex cord-stromal tumors including two fibromas, two fibrothecomas, six adult granulosa cell tumors (GCT), three Sertoli-Leydig cell tumors (SLCT) and one Leydig cell tumors (LCT) and one dysgerminoma. Non-neoplastic ovarian tissue adjacent to tumor and of two additional samples from postmenopausal ovaries without a neoplasm was also investigated. The tissue was stored at $-80^{\circ} \mathrm{C}$.

\section{Tumor cell lines}

The human ovary adenocarcinoma cell lines SK-OV3 and NIH:OVCAR-3 were obtained from the American Type Culture Collection (Manassas, VA, USA). SK-OV-3 cells were grown in McCoy's 5a medium supplemented with $1.5 \mathrm{mM}$ glutamine, $1.5 \mathrm{~g} / \mathrm{l}$ sodium bicarbonate, $10 \%$ fetal bovine serum, $100 \mathrm{U} /$ $\mathrm{ml}$ penicillin, and $100 \mu \mathrm{g} / \mathrm{ml}$ streptomycin. NIH:OVCAR-3 cells were grown in RPMI 1640 medium supplemented with $2 \mathrm{mM}$ glutamine, $10 \mathrm{mM}$ HEPES, $1 \mathrm{mM}$ sodium pyruvate, $4.5 \mathrm{~g} / \mathrm{l}$ glucose, $1.5 \mathrm{~g} / \mathrm{l}$ sodium bicarbonate, $0.01 \mathrm{mg} / \mathrm{ml}$ bovine insulin, $20 \%$ fetal bovine serum, $100 \mathrm{U} / \mathrm{ml}$ penicillin, and $100 \mu \mathrm{g} / \mathrm{ml}$ streptomycin. The human ovary adenocarcinoma cell line EFO-27 was obtained from DSMZ (Deutsche Sammlung von Mikroorganismen und Zellkulturen $\mathrm{GmbH}$, Braunschweig, Germany) and grown in RPMI 1640 medium supplemented with $2 \mathrm{mM}$ glutamine, $0.1 \mathrm{mM}$ MEM nonessential amino acids, $1 \mathrm{mM}$ sodium pyruvate, $20 \%$ fetal bovine serum, $100 \mathrm{U} / \mathrm{ml}$ penicillin, and $100 \mu \mathrm{g} / \mathrm{ml}$ streptomycin. All three human ovary adenocarcinoma cell lines were grown in a humidified $5 \% \mathrm{CO}_{2}$ atmosphere at $37^{\circ} \mathrm{C}$. All cell culture reagents were supplied by GIBCO/BRL, Life Technologies (Grand Island, NY, USA), except for glucose and bovine insulin, which were supplied from Sigma (St Louis, MO, USA). Cells were washed twice with and scraped into ice-cold $0.05 \mathrm{M}$ Tris-HCl (pH 7.4), collected by centrifugation, and homogenized using a rotor/stator slash system (Polytron, Kinematica Inc., Littau, Switzerland) in the same buffer. After centrifugation at $120 \mathrm{~g}$ for $5 \mathrm{~min}$ at $4^{\circ} \mathrm{C}$, the supernatant was collected and centrifuged again at $48000 \mathrm{~g}$ for $30 \mathrm{~min}$ at $4^{\circ} \mathrm{C}$. The resulting pellet was resuspended in ice-cold Tris buffer, transferred into a microfuge tube, and centrifuged at $20000 \mathrm{~g}$ for $15 \mathrm{~min}$ at $4^{\circ} \mathrm{C}$. After withdrawal of the supernatant, the membrane pellet was stored at $-80^{\circ} \mathrm{C}$.

\section{NPY Receptor Autoradiography}

Cryostat sections of $20 \mu \mathrm{m}$ thickness were mounted on precleaned slides and stored at $-20^{\circ} \mathrm{C}$ for several days to improve adhesion of the tissue to the slides. The slides were preincubated in Krebs-Ringer solution ( $\mathrm{NaCl} 119 \mathrm{mM}, \quad \mathrm{KCl} \quad 3.2 \mathrm{mM}, \quad \mathrm{KH}_{2} \mathrm{PO}_{4}$ $1.19 \mathrm{mM}, \mathrm{MgSO}_{4} 1.19 \mathrm{mM}, \mathrm{NaHCO}_{3} 25 \mathrm{mM}, \mathrm{CaCl}_{2}$ $2.53 \mathrm{mM}$, D-glucose $10 \mathrm{mM}$; pH 7.4 ) for $60 \mathrm{~min}$ at room temperature. Then they were incubated for $120 \mathrm{~min}$ in the incubation solution containing the Krebs-Ringer solution, 0.1\% BSA, 0.05\% bacitracin, and $10000 \mathrm{cpm} / 100 \mu \mathrm{l}$ of the ${ }^{125}$ I-labeled radioligand human PYY (hPYY; $2000 \mathrm{Ci} / \mathrm{mmol}$; Anawa, Wangen, Switzerland), as described previously. ${ }^{6}$ To assess nonspecific binding, tissue sections were incubated with the above-mentioned incubation solution and 
$25 \mathrm{nM}$ nonlabeled hPYY. To distinguish specific receptor subtypes, displacement experiments were performed with various subtype-selective analogs. Serial tissue sections were incubated with ${ }^{125} \mathrm{I}-$ labeled hPYY and increasing concentrations of one of the following nonlabeled ligands: the universal ligand hPYY (Bachem, Bubendorf, Switzerland), the Y1-selective ligands [Leu $\left.{ }^{31}, \mathrm{Pro}^{34}\right]$-hPYY (Bachem, Bubendorf, Switzerland) or BIBP 3226 (Böhringer, Ingelheim, Germany), the Y2-selective ligands hPYY(3-36) (Bachem, Bubendorf, Switzerland) or BIIE 0246 (Böhringer, Ingelheim, Germany), the Y4 preferring ligand human PP (hPP; Bachem, Bubendorf, Switzerland), or the Y5-selective [ $\left[\mathrm{Ala}^{31}, \mathrm{Aib}^{32}\right]$ hNPY (Dr A Beck-Sickinger, Leipzig), respectively. After incubation, the slides were washed two times for $5 \mathrm{~min}$ and then rinsed four times in ice-cold preincubation solution. After drying under a stream of cold air at $4^{\circ} \mathrm{C}$, the slides were exposed to Kodak films Biomax $\mathrm{MR}^{\circledR}$ for 7 days at $4^{\circ} \mathrm{C}$. The resulting signals were analyzed, and receptor positive cases were assessed quantitatively using a computerassisted image processing system (Analysis Imaging System, Interfocus, Mering, Germany). Tissue standards for iodinated compounds (Amersham, Aylesbury, UK) were used for this purpose. In all experiments, rat brain sections served as positive controls, Y1 being highly expressed in the brain cortex and Y2 in the hippocampus. ${ }^{19}$

\section{Immunohistochemistry for Inhibin}

Immunohistochemistry for inhibin was performed in all GCT, SLCT, and LCT, and in 12 adenocarcinomas (nine serous, two endometrioid, one mucinous; seven of them were positive, five were negative for NPY receptors). Cryostat sections of $10 \mu \mathrm{m}$ thickness of fresh frozen tissue postfixed in formalin, or $4 \mu \mathrm{m}$ thick paraffin sections of formalinfixed tissue were used. The primary antibody was a monoclonal mouse antibody directed against the inhibin $\alpha$ subunit (1:20; DAKO, Zug. Switzerland), and the secondary antibody was a biotinylated goat anti-mouse immunoglobulin. Antibody binding was visualized by the ABComplex/HRP (DAKO). Staining was performed with $\mathrm{DAB}$, and counterstaining with hemalum.

\section{Results}

\section{NPY Receptor Expression in Neoplastic Tissue}

Table 1 summarizes the obtained data. The incidence of NPY receptors varied considerably from one tumor type to another. Incidence was highest in GCT, SLCT, and LCT $(100 \%)$. It was much lower in adenocarcinomas $(32 \%)$. Receptors were not detected in any of the investigated adenomas, borderline tumors, pure stromal neoplasms, or in the dysgerminoma. Figure 1 shows two typical and
Table 1 Incidence of NPY receptors in ovarian tumors

\begin{tabular}{lc}
\hline Tumor type & $\begin{array}{c}\text { NPY receptor } \\
\text { positive cases }\end{array}$ \\
\hline Surface epithelial-stromal tumors & \\
Adenomas & $0 / 3(0 \%)$ \\
Borderline tumors & $0 / 3(0 \%)$ \\
Adenocarcinomas & \\
$\quad$ Serous & $4 / 14(29 \%)$ \\
$\quad$ Endometrioid & $2 / 5(40 \%)$ \\
$\quad$ Mucinous & $1 / 3(33 \%)$ \\
Sex cord-stromal tumors & \\
GCT & $6 / 6(100 \%)$ \\
SLCT & $3 / 3(100 \%)$ \\
LCT & $1 / 1(100 \%)$ \\
Fibromas/fibrothecomas & $0 / 4(0 \%)$ \\
Germ cell tumor & \\
Dysgerminoma & $0 / 1(0 \%)$ \\
\hline
\end{tabular}

representative examples of NPY receptor expression in GCT. The two GCT are well identified by immunostaining for inhibin, and the NPY receptors are exclusively located in inhibin-positive areas. The tumor surroundings represent non-neoplastic ovarian stroma. Figure 1 illustrates how much the receptor distribution and the density can vary between different tumors. In the case on the lefthand side, a strong and homogeneous labeling with the universal ligand ${ }^{125} \mathrm{I}-\mathrm{hPYY}$ is observed in the whole tissue. In contrast, in the case on the right, the NPY receptor density is much lower and restricted to small areas of the tumor sample. Control sections incubated with $25 \mathrm{nM}$ nonlabeled hPYY show the nonspecific binding.

\section{NPY Receptor Subtypes and Their Density in Sex Cord-Stromal Tumors}

Table 2 indicates the receptor subtypes expressed in the sex cord-stromal tumors, their density, and overall distribution. The great majority of the tumors express both $\mathrm{Y} 1$ and Y2 subtypes that are not necessarily present in the same areas. The density varies very much with more than 10 times difference from one tumor to the other. There is a tendency for LCT and SLCT to express more Y2, whereas GCT express more Y1. The mean receptor densities for all sex cord-stromal tumors is $877 \mathrm{dpm} / \mathrm{mg}$ for the Y1 receptor and $911 \mathrm{dpm} / \mathrm{mg}$ for the Y2 receptor, which is much lower than the density found in breast carcinomas. ${ }^{6}$ The receptor distribution is in most cases heterogeneous within the tumor sample. For instance, Y2 receptor density in case no. 4 ranges from $416 \mathrm{dpm} / \mathrm{mg}$ in areas with low receptor expression to $2981 \mathrm{dpm} / \mathrm{mg}$ in areas with high receptor expression, with a mean of $1058 \mathrm{dpm} / \mathrm{mg}$. NPY receptors seem to be expressed irrespective of the clinical course (Table 2). Figure 2 shows examples of the receptor subtype characterization 
74
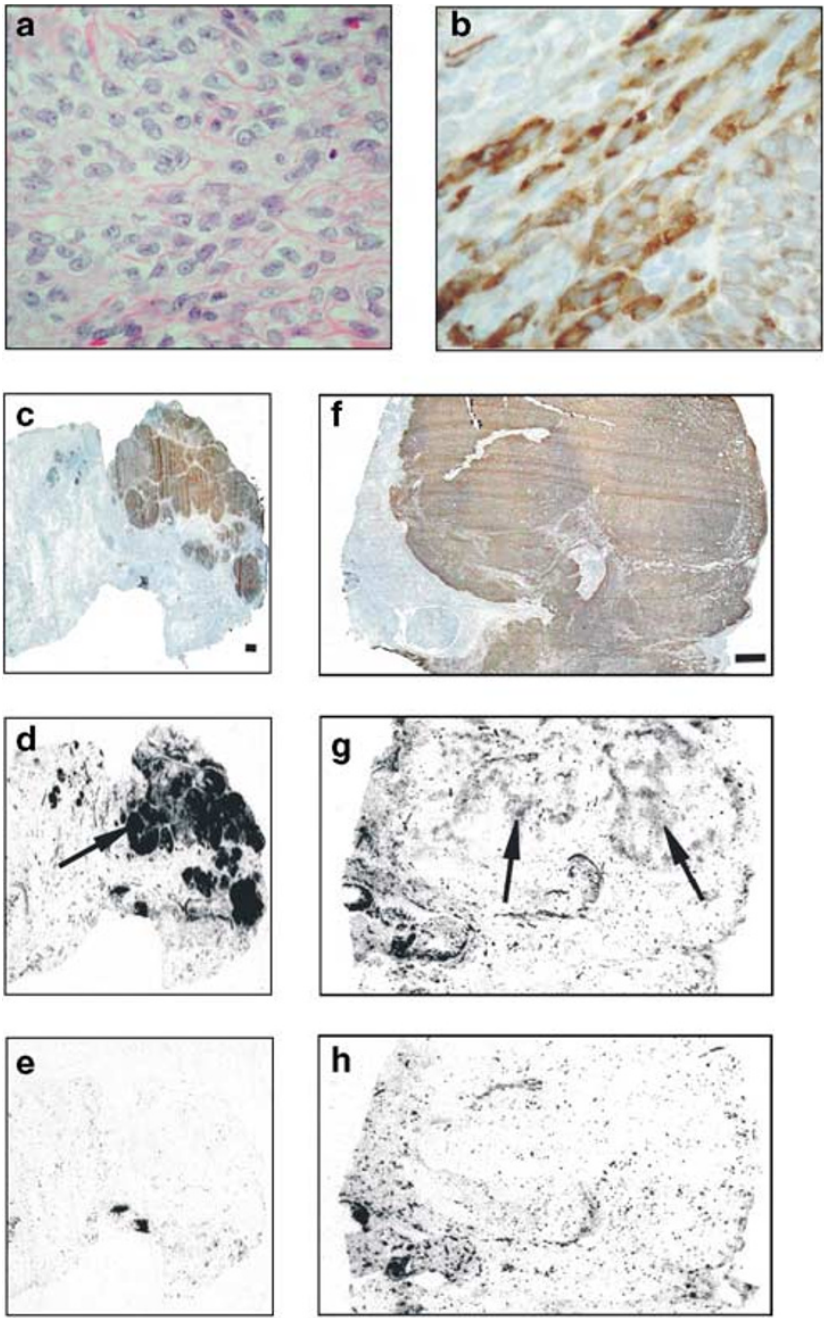

Figure 1 NPY receptors detected by receptor autoradiography in two different GCT (c-e and f-h). (a) Typical histomorphology: diffuse growth of single cells with elongated nuclei and occasional nuclear grooves in an $\mathrm{HE}$ section $(\times 400)$. (b) Many tumor cells immunostain strongly for inhibin $(\times 400)$. (c) Immunohistochemistry for inhibin shows the homogeneous staining of a GCT on the upper right of the tissue section. Bar $=1 \mathrm{~mm}$. (d) Autoradiogram showing total binding of the universal ligand ${ }^{125} \mathrm{I}-\mathrm{hPYY}$ with strong labeling of the entire tumor tissue (arrow). (e) Autoradiogram showing nonspecific binding of ${ }^{125} \mathrm{I}-\mathrm{hPYY}$ in the presence of $25 \mathrm{nM}$ cold hPYY. (f) Immunohistochemistry for inhibin shows another case of a GCT homogeneously stained located on the right side of the tissue section. (g) Autoradiogram showing total binding of the universal ligand ${ }^{125}$ I-hPYY with only focal, moderate labeling of the tumor tissue (arrows). (h) Autoradiogram showing nonspecific binding of ${ }^{125} \mathrm{I}-\mathrm{hPYY}$ in the presence of $25 \mathrm{nM}$ cold $\mathrm{hPYY}$.

of a GCT and an LCT. Both cases have a strong expression of NPY receptors. However, the GCT expresses predominantly Y1 whereas the LCT has Y2. Figure 2(a-d) shows the GCT. The HE-stained section at the top reveals a solid tumor nest in the upper field and several isolated nests scattered throughout the remaining tissue. The labeling of ${ }^{125} \mathrm{I}$-hPYY is strong and homogeneous throughout the tumor sample. Displacement of ${ }^{125} \mathrm{I}-\mathrm{hPYY}$ is achieved with $25 \mathrm{nM}$ of the Y1 receptor-selective ligand $\left[\mathrm{Leu}^{31}, \mathrm{Pro}^{34}\right]$-hPYY, whereas no displacement is seen with the $\mathrm{Y} 2$ receptor-selective ligand hPYY(3-36). Figure 2(e-h) shows the LCT on the right part of the tissue section and adjacent ovarian stroma on the left side. Here, by contrast, ${ }^{125} \mathrm{I}-\mathrm{hPYY}$ is selectively displaced by $\mathrm{hPYY}(3-36)$, but not by $\left[\mathrm{Leu}^{31}, \mathrm{Pro}^{34}\right]$-hPYY, proving that this is a predominantly Y2-expressing tumor.

\section{NPY Receptor Subtypes and Their Density in Adenocarcinomas}

Table 3 shows the NPY receptor subtyping, densities, and distribution in all NPY receptor-expressing adenocarcinomas tested. NPY receptor labeling was observed over neoplastic epithelial cells. No relationship between histologic grade or adenocarcinoma subtype and presence of receptors was detectable. Typically, receptors were restricted to certain tumor areas. Usually, only a small area of the investigated tissue showed NPY receptors. The mean receptor density of the positive adenocarcinoma cases was mostly low, on average lower than in sex cord-stromal tumors. Y1 and Y2 receptors were usually concomitantly present, with a predominance of Y2. Figure 3 shows an example of an NPY receptor-expressing adenocarcinoma. The HE section shows the tumor surrounded by necrotic areas without adjacent ovarian stroma. ${ }^{125} \mathrm{I}$-hPYY labels in varying density larger parts of the tumor, with complete displacement in all ${ }^{125} \mathrm{I}$-hPYY-labeled tumoral areas achieved with the Y2-selective ligand hPYY(3-36), but only marginal displacement by the Y1-selective ligand.

\section{NPY Receptors in Ovarian Carcinoma Cell Lines}

Three ovarian carcinoma cell lines, NIH OVCAR3, EFO27, and SKOV3, were tested for their NPY receptor content using in vitro receptor autoradiography on cell pellets. None of the tumor cell lines contained measurable amounts of NPY receptors, indicating that these cell lines do not represent an adequate model for functional investigations.

\section{Pharmacological Characterization of Y1 and Y2}

The pharmacological characterization of Y1 and Y2 subtypes is performed in competition experiments with increasing concentrations of various subtypeselective ligands to assess their rank order of potency. Figure 4 shows two representative competition experiments. In a Y1-expressing GCT, the Y1selective [ $\mathrm{Leu}^{31}, \mathrm{Pro}^{34}$ ]-hPYY and BIBP 3226 completely displace the radiotracer with high affinity, whereas the Y2-selective hPYY(3-36) and BIIE 0246 displace it with low affinity. The opposite is observed in the Y2-expressing LCT, namely complete displacement in the high-affinity range with 
Table 2 NPY receptor subtype characterization and density in sex cord-stromal tumors

\begin{tabular}{|c|c|c|c|c|}
\hline \multirow[t]{2}{*}{ Tumor type } & \multicolumn{2}{|c|}{ Receptor subtype with density (dpm/mg) } & \multirow{2}{*}{$\begin{array}{l}\text { Receptor } \\
\text { distribution }\end{array}$} & \multirow{2}{*}{$\begin{array}{l}\text { Clinical course } \\
\text { (maximum follow-up) }\end{array}$} \\
\hline & $Y 1$ & $Y 2$ & & \\
\hline No. 1 LCT & 0 & 3027 & Homogeneous & NA \\
\hline No. 2 SLCT, intermediate differentiation & 779 & 166 & Heterogeneous & Recurrent; NED (7 years) \\
\hline No. 3 SLCT, intermediate differentiation & 296 & 1342 & Heterogeneous & DOD (19 months) \\
\hline No. 4 SLCT, intermediate differentiation & 130 & 1058 & Heterogeneous & NA \\
\hline Mean density SLCT and LCT (mean \pm s.e.m.) & $301 \pm 170$ & $1398 \pm 598$ & & \\
\hline No. 5 GCT & 259 & 361 & Heterogeneous & Recurrent; AWD (12 years) \\
\hline No. 6 GCT & 666 & 29 & Heterogeneous & Recurrent; AWD (20 years) \\
\hline No. 7 GCT & 3850 & 1225 & Heterogeneous & NED (1 year) \\
\hline No. 8 GCT & 551 & 707 & Heterogeneous & NED (15 months) \\
\hline No. 9 GCT & 2052 & 510 & Heterogeneous & NA \\
\hline No. 10 GCT & 191 & 692 & Heterogeneous & NA \\
\hline Mean density GCT (mean \pm s.e.m.) & $1262 \pm 587$ & $587 \pm 163$ & & \\
\hline Overall mean density (mean \pm s.e.m.) & $877 \pm 376$ & $911 \pm 272$ & & \\
\hline
\end{tabular}

LCT = Leydig cell tumor; SLCT = Sertoli-Leydig cell tumor; GCT = granulosa cell tumor; NA = not available; NED = no evidence of disease; $\mathrm{AWD}=$ alive with disease $\mathrm{DOD}=$ dead of disease

\section{Granulosa cell tumor}

Y1
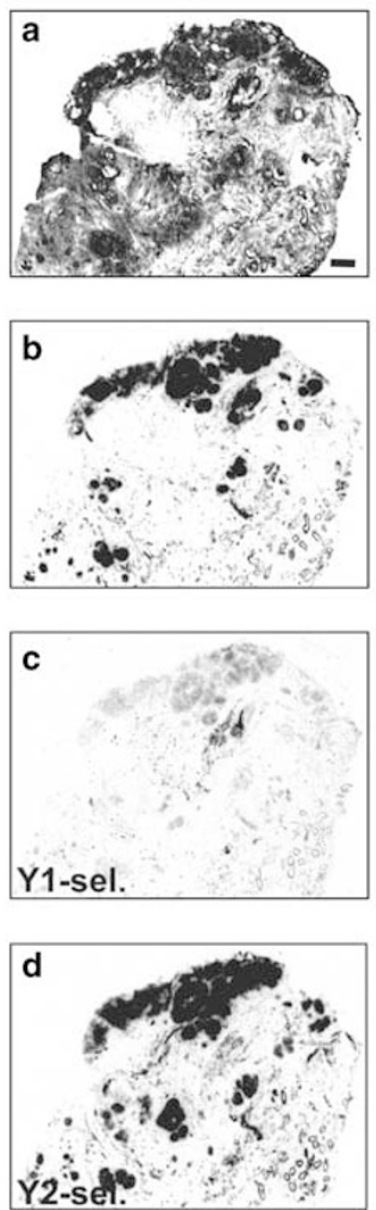

\section{Leydig cell tumor} Y2
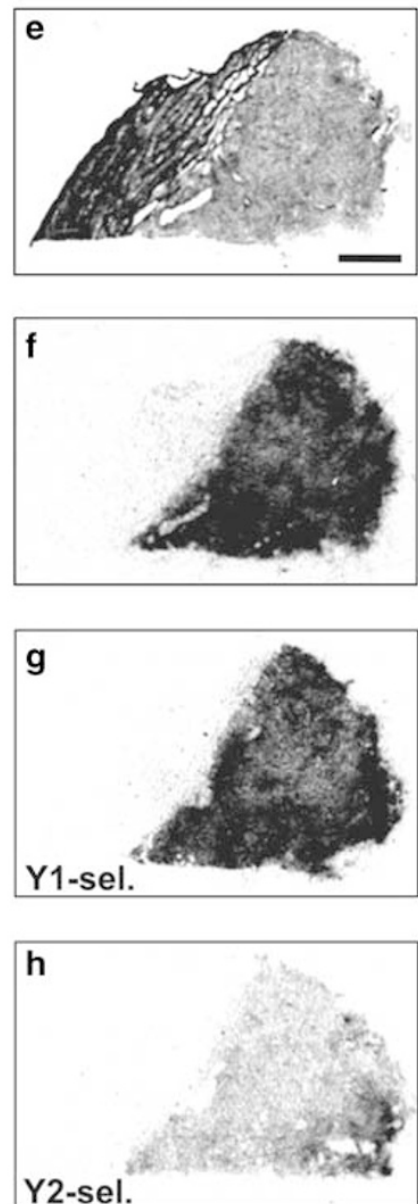

Table 3 NPY receptor subtype characterization and density in ovarian adenocarcinomas

\begin{tabular}{lccl}
\hline Tumor type & $\begin{array}{c}\text { Receptor subtype } \\
\text { with density } \\
\text { (dpm/mg) }\end{array}$ & $\begin{array}{l}\text { Receptor } \\
\text { distribution }\end{array}$ \\
\cline { 2 - 3 } & $Y 1$ & $Y 2$ & \\
\hline $\begin{array}{l}\text { No. 11 Serous papillary } \\
\text { adenocarcinoma, grade 1 }\end{array}$ & 214 & 307 & Heterogeneous \\
$\begin{array}{l}\text { No. 12 Serous papillary } \\
\text { adenocarcinoma, grade } 2\end{array}$ & 440 & 0 & Heterogeneous \\
$\begin{array}{l}\text { No. 13 Serous papillary } \\
\text { adenocarcinoma, grade 2 }\end{array}$ & 580 & 649 & Heterogeneous \\
$\begin{array}{l}\text { No. 14 Serous papillary } \\
\text { adenocarcinoma, grade 3 }\end{array}$ & 250 & 454 & Heterogeneous \\
$\begin{array}{l}\text { No. 15 Mucinous } \\
\text { adenocarcinoma, grade 1 }\end{array}$ & 595 & 1582 & Heterogeneous \\
$\begin{array}{l}\text { No. 16 Endometrioid } \\
\text { adenocarcinoma, grade } 3\end{array}$ & 184 & 322 & Heterogeneous \\
$\begin{array}{l}\text { No. 17 Endometrioid } \\
\text { adenocarcinoma, grde } 2\end{array}$ & 619 & 1143 & Heterogeneous
\end{tabular}

Mean density (mean \pm s.e.m.) $412 \pm 73 \quad 637 \pm 207$

Figure 2 NPY receptor subtypes in a GCT $(\mathbf{a}-\mathbf{d})$ and an LCT $(\mathbf{e}-\mathbf{h})$. (a and e) HE-stained sections showing the GCT (a) with a large solid part at the upper margin surrounded by scattered smaller nests and the LCT (e) on the right side of the sample. Bars $=1 \mathrm{~mm}$. $(\mathbf{b}, \mathbf{f})$ Autoradiograms showing total binding of the universal ligand ${ }^{125} \mathrm{I}$-hPYY with strong and homogeneous labeling in both cases. (c, g) Autoradiograms showing ${ }^{125} \mathrm{I}-\mathrm{hPYY}$ binding in the presence of $25 \mathrm{nM}$ of the Y1-selective ligand $\left[\mathrm{Leu}^{31}, \mathrm{Pro}^{34}\right]$-hPYY. In the GCT, there is almost complete displacement of ${ }^{125} \mathrm{I}$-hPYY by $\left[\mathrm{Leu}^{31}, \mathrm{Pro}^{34}\right]$-hPYY at the receptor (c). In the LCT, there is no displacement by [Leu $\left.{ }^{31}, \mathrm{Pro}^{34}\right]$-hPYY (g). (d, h) Autoradiograms showing ${ }^{125} \mathrm{I}$-hPYY binding in the presence of $25 \mathrm{nM}$ of the Y2selective ligand hPYY(3-36). In the GCT, no displacement of ${ }^{125} \mathrm{I}-$ hPYY by hPYY(3-36) at the receptor can be observed (d), whereas displacement is observed in the LCT (h). This shows that the GCT has predominantly $\mathrm{Y} 1$, and the LCT has predominantly Y2 receptors. 

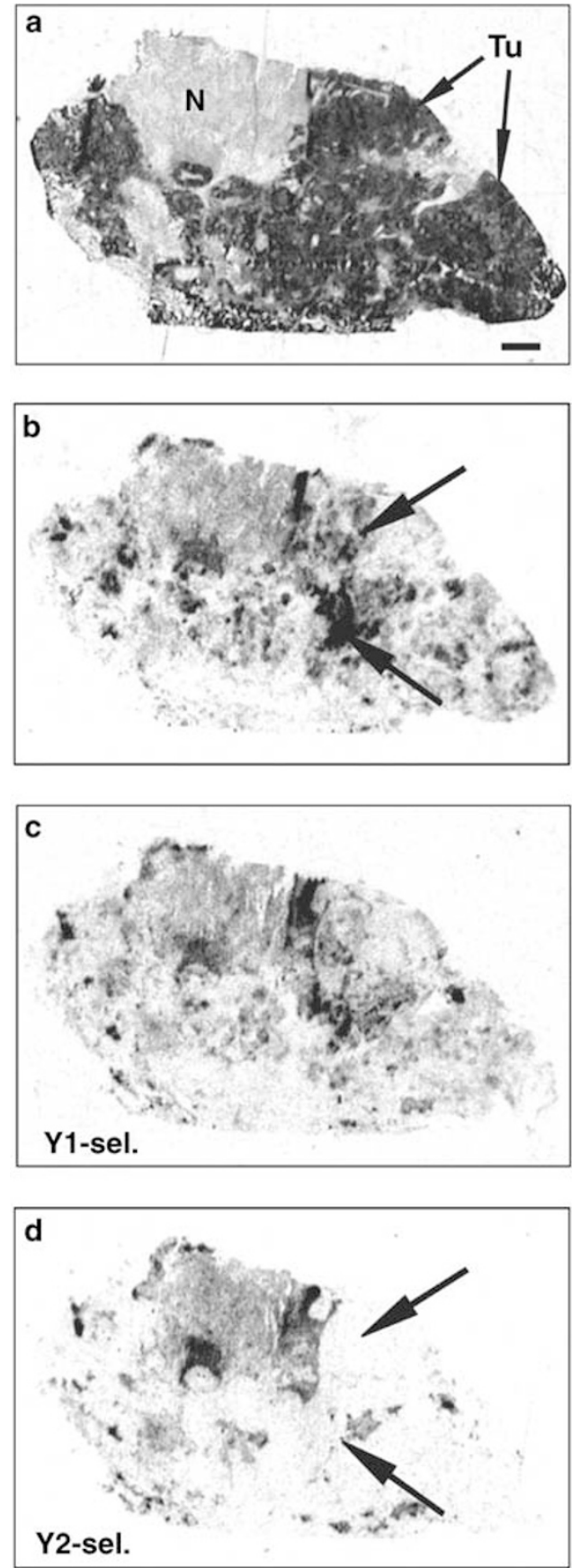

Figure 3 NPY receptors in an ovarian adenocarcinoma. (a) HEstained section of a serous adenocarcinoma of poor differentiation $(\mathrm{Tu})$ surrounded by necrotic areas $(\mathrm{N})$. Bar $=1 \mathrm{~mm}$. (b) Autoradiogram showing total binding of the universal ligand ${ }^{125} \mathrm{I}$-hPYY in the tumor (arrows). A marked heterogeneous labeling is observed. (c) Autoradiogram showing ${ }^{125} \mathrm{I}$-hPYY binding in the presence of $25 \mathrm{nM}$ of the Y1-selective ligand [ $\mathrm{Leu}^{31}$, Pro $\left.{ }^{34}\right]$-hPYY, showing only marginal displacement of ${ }^{125} \mathrm{I}$-hPYY. (d) Autoradiogram showing ${ }^{125} \mathrm{I}-\mathrm{hPYY}$ binding in the presence of $25 \mathrm{nM}$ of the Y2-selective ligand hPYY(3-36). hPYY(3-36) fully displaces the universal ligand in the tumoral areas (arrows). This tumor expresses therefore preferentially Y2 receptors. Nonspecific binding is present in necrotic areas. a Granulosa cell tumor

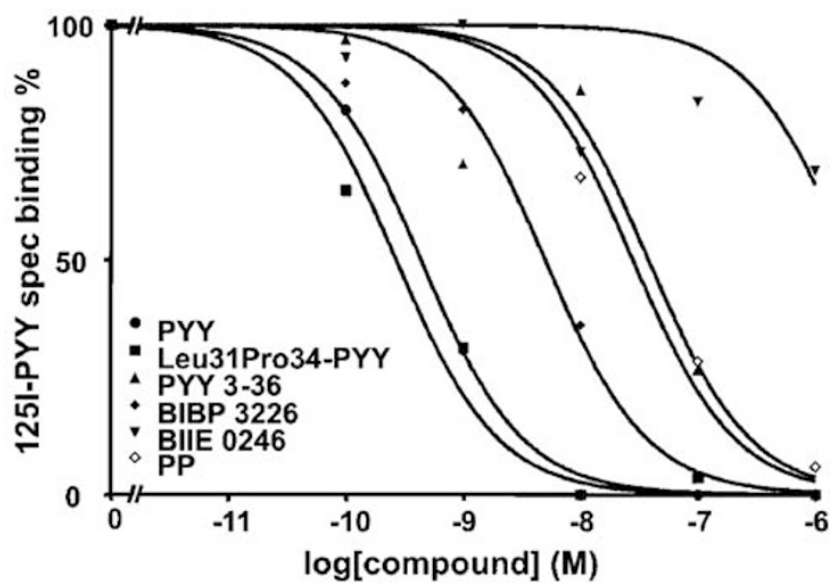

b

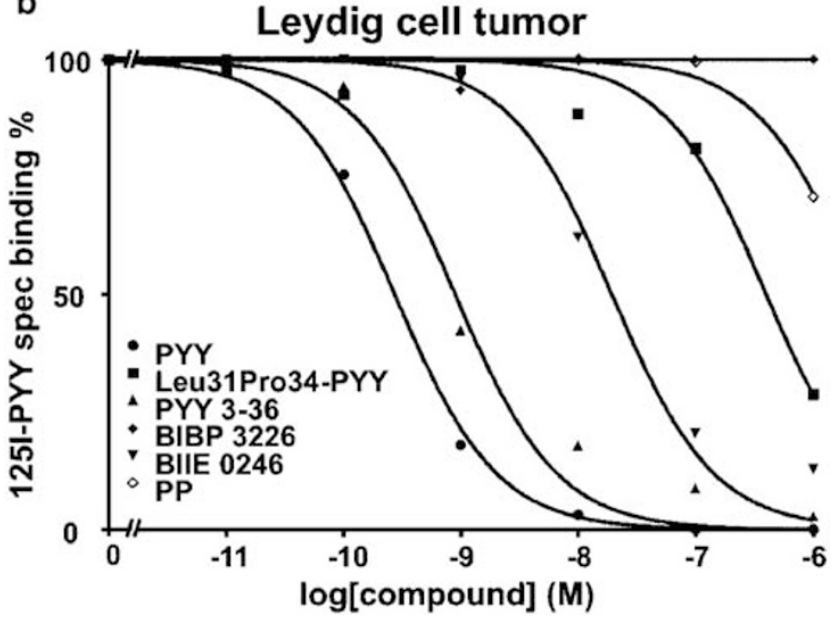

Figure 4 Competition experiments in a Y1-expressing GCT (a) and a Y2-expressing LCT (b). (a) High-affinity displacement of ${ }^{125}$ I-hPYY by hPYY ( ), [Leu ${ }^{31}$, Pro ${ }^{34}$ ]-hPYY ( $)$, and BIBP 3226 $(\diamond)$, but low-affinity displacement by hPYY(3-36) (A) or BIIE $0246(\boldsymbol{\nabla})$ is characteristic for Y1 receptors. hPP $(\diamond)$ is weakly active. (b) High-affinity displacement of ${ }^{125}$ I-hPYY by hPYY ( $(\bullet)$ and hPYY(3-36) (A), moderate-affinity displacement by BIIE 0246 $(\boldsymbol{\nabla})$, but low-affinity displacement by $\left[\mathrm{Leu}^{31}, \mathrm{Pro}^{34}\right]$-hPYY (ם), and no displacement by BIBP $3226(\bullet)$ is characteristic for Y2 receptors. hPP $(\diamond)$ has very low affinity.

the Y2-selective hPYY(3-36) and BIIE 0246, compared to lower affinity displacement with the Y1selective [Leu ${ }^{31}$, Pro $\left.^{34}\right]$-hPYY and BIBP 3226. The synthetic analogs BIBP 3226 and BIIE 0246 show lower affinity than $\left[\mathrm{Leu}^{31}, \mathrm{Pro}^{34}\right]$-hPYY, and hPYY(3-36), respectively, but display a strong selectivity for the respective receptor subtypes, in agreement with previous reports. ${ }^{20,21}$ The presence of Y4 can be ruled out due to the low affinity of hPP in all NPY receptor-expressing tumors. The Y5selective analog $\left[\mathrm{Ala}^{31}, \mathrm{Aib}^{32}\right]$-hNPY is inactive in all cases. Similar rank orders of potencies are found in control tissues, namely in Y2-expressing breast carcinoma, ${ }^{6}$ Y1-expressing rat cortex, and Y2-expressing rat hippocampus. 


\section{Inhibin Expression}

Inhibin is demonstrated by immunohistochemistry in all GCT, LCT, and SLCT, as expected from the literature,$^{22-24}$ further confirming the histopathological diagnoses. Figure 1 shows two typical examples of GCT stained for inhibin. Staining is usually strong and homogeneous throughout the entire tumor sample. In addition, inhibin immunostaining is positive in three of the 12 investigated adenocarcinomas. It is seen focally in stromal cells of an endometrioid, a mucinous, and a serous adenocarcinoma. In the latter two cases, also small groups of epithelial cells stain for inhibin. However, among these inhibin-positive adenocarcinomas, only the mucinous adenocarcinoma is positive for NPY receptors. Investigation of serial sections of this adenocarcinoma reveals that labeling of NPY receptors and staining for inhibin are not necessarily located in the same tumor areas. All other NPY receptor-positive adenocarcinoma samples and the investigated NPY receptor-negative adenocarcinoma samples are negative for inhibin.

\section{NPY Receptor Expression in Non-neoplastic Ovarian Tissue}

We were also able to identify NPY receptors in the blood vessels within tumors or in the surroundings of tumors in 23 of 34 cases. Vessels in the normal ovarian stroma are positive for NPY receptors in 14 of 18 samples (78\%). Intratumoral vessels express NPY receptors in 11 of 26 cases (42\%). The receptors are located in the smooth muscle layer and are all characterized as Y1. The receptor density varies, but is usually moderate to high and comparable in normal and intratumoral vessels. In one case, a hilus cell aggregate is strongly positive for Y2. In two cases, Y1 is expressed in the perivascular tissue restricted to hilus vessels. Apart from these instances, no receptors are observed in genuine or neoplastic ovarian stroma.

\section{Discussion}

The present study shows that all GCT, LCT, and SLCT express NPY receptors. Such a frequent NPY receptor expression in sex cord-stromal tumors is completely unexpected, as NPY has no established role in the ovarian cells giving rise to these neoplasms. It is not less unexpected that even ovarian adenocarcinomas can express NPY receptors, although with a lower incidence and density. This study is the first indication that NPY receptors may represent a new biological cell marker and potential clinical target in these ovarian cancers. The present data can be added and compared to those reported previously in the carcinomas of the breast, where NPY receptors are present in $85 \%$ of the cases, often in very high density, and preferably as Y1 subtype. ${ }^{6,7}$

Several NPY receptor subtypes have been reported to exist in humans, including Y1, Y2, Y4, and Y5, whereas Y6 was detected only at the mRNA level. ${ }^{8}$ The present study, by performing displacement experiments with several subtype-selective analogs, provides very strong arguments in favor of the presence of Y1 and Y2 receptor subtypes in ovarian tumors, often expressed concomitantly in individual tumors. Pharmacological evidence of a specific $\mathrm{Y} 1$ receptor detection in this study is given when the binding of the universal ligand ${ }^{125} \mathrm{I}-\mathrm{hPYY}$ is displaced in the high-affinity range by the Y1-selective ligand $\left[\mathrm{Leu}^{31}, \mathrm{Pro}^{34}\right]-\mathrm{hPYY}$ but not by the Y2selective ligand hPYY(3-36). Additional proof for Y1 expression is given when the Y1-selective synthetic nonpeptide analog BIBP 3226 has a moderate to high affinity to the receptor, as reported in previous studies, ${ }^{21}$ while the Y2-selective synthetic nonpeptide analog BIIE 0246 shows a very low affinity, as reported previously. ${ }^{20}$ The presence of Y4 or Y5 can be ruled out since hPP, known to have a very high affinity for $\mathrm{Y}^{4},{ }^{8}$ and the Y5selective nonpeptide analog $\left[\mathrm{Ala}^{31}, \mathrm{Aib}^{32}\right]-\mathrm{hNPY}^{25}$ show low or no affinity. Conversely, pharmacological evidence of expression of the $\mathrm{Y} 2$ receptor is given when binding of the universal ligand ${ }^{125} \mathrm{I}-$ hPYY is displaced by the Y2-selective analogs hPYY(3-36) and BIIE 0246 in the moderate to high affinity range, whereas the Y1-selective analogs $\left[\mathrm{Leu}^{31}, \mathrm{Pro}^{34}\right]$-hPYY and BIBP 3226 , as well as the Y4 preferring hPP and the Y5-selective ligand [Ala ${ }^{31}$, $\mathrm{Aib}^{32}$ ]-hNPY show low or no affinity. A comparable rank order of potencies has been obtained for control tissues, namely the rat cortex for $\mathrm{Y} 1,{ }^{19}$ and rat hippocampus and breast carcinoma for Y2, 6,19 further confirming the results in ovarian neoplasms.

Although a systematic investigation of normal ovarian tissue could not be performed, due to restricted availability of premenopausal ovarian tissue, it is the first description of NPY receptors in the non-neoplastic human ovary. The Y1 receptor incidence in vessels adjacent to the tumors and in normal ovarian stroma is remarkably high, in agreement with the previous reports of Y1 receptors in vessels in various organs of rats and humans. ${ }^{26,27}$ The Y1 receptor incidence in intratumoral vessels appears to be lower. This can be explained by the fact that NPY receptors are expressed in vascular smooth muscle cells that are less prominent in newly formed intratumoral vessels than in normal vessels. Apart from the receptors in the vascular smooth muscle, we identified NPY receptors in the perivascular stroma of hilus vessels and even in a hilus cell aggregate. These cell groups correspond to lutein-like cells. ${ }^{28}$ The lutein-like cells in the ovarian hilus are homologous to the Leydig cells in LCT and SLCT. Therefore, the strong Y2 positivity observed in the hilar cell aggregate is well in accordance with the Y2 positivity of the LCT and 
the majority of the SLCT. The NPY receptors in the normal ovary may be the targets of endogenous NPY that was detected in human ovaries by immunohistochemistry: many nerve fibers indeed, those innervating blood vessels as well as those localized within the stroma and between follicles contain NPY. ${ }^{29}$ No NPY receptors were observed in the ovarian surface epithelium, the tissue of origin of ovarian adenocarcinomas. This suggests that the NPY receptors in adenocarcinomas may be expressed de novo, explaining perhaps their low incidence, low density, and focal distribution.

A functional role of NPY in the human ovary is not established; the few available investigations are restricted to animals. For instance, in the rabbit ovarian artery, NPY was shown in vitro to influence the vascular tone by Y1-mediated mechanisms. ${ }^{30} \mathrm{~A}$ similar function may be extrapolated to human ovarian vessels based on the strong presence of Y1 receptors in the ovarian vasculature. Furthermore, in human granulosa cell cultures, NPY regulates steroid hormone production together with a considerable stimulation of estrogen release. ${ }^{31}$ The significance of such a mechanism in vivo is not clear. It suggests that NPY receptors are physiologically present on human granulosa cells, in accordance with the expression of NPY receptors found in GCT in the present study. Furthermore, since GCT usually produce high levels of estrogen, ${ }^{32}$ a possible role of NPY receptors in the regulation of the estrogen metabolism in these tumors may be suggested and worth investigating in future studies.

The present study confirms that the expression of the inhibin $\alpha$ subunit can be detected by immunohistochemistry in sex cord-stromal tumors, ${ }^{22,23}$ while it is much rarer in the epithelial cells of ovarian adenocarcinomas. ${ }^{22,33}$ The presence of NPY receptors in inhibin-expressing sex cord-stromal tumors may be indicative of an NPY action on the inhibin system; NPY may affect inhibin production and/or release and, as such, play a pathophysiological role in inhibin-producing tumors. Moreover, inhibin may have growth-suppressive functions in these tumors, since inhibin-deficient mice develop malignant sex cord-stromal tumors in very high frequency. ${ }^{24}$

The present therapeutic strategies for ovarian cancers are not optimal as $75 \%$ of the patients with adenocarcinoma present with advanced tumor stage, require chemotherapy, ${ }^{34,35}$ and have a poor prognosis. ${ }^{16}$ The 5-year survival rate for patients with widespread disease is only $10-20 \% .{ }^{16}$ GCT are characterized by an unpredictable, variable, and long clinical course with multiple and late recurrences and metastases. ${ }^{17}$ SLCT are relatively uncommon neoplasms with an excellent prognosis when diagnosed at an early stage. Higher stage, poor histologic differentiation, and presence of heterologous elements are, however, afflicted with poor outcome. ${ }^{36}$ Management of advanced disease of GCT and SLCT comprises chemotherapy and radiotherapy that show considerable side effects and generally poor long-term results. ${ }^{17,37}$ Therefore, novel imaging procedures for follow-up and therapeutic approaches for both adenocarcinomas and malignant sex cord-stromal tumors are desirable. For neoplasms that express peptide hormone receptors in high density and incidence, the novel method of in vivo receptor targeting is an attractive option. This is the case for adenocarcinomas of the breast expressing Y1. ${ }^{6,7}$ Selected ovarian tumors may also fulfill these criteria. Especially GCT and SLCT are qualified due to the very high incidence of NPY receptors. Radiolabeled NPY analogs could potentially be used for diagnostic scintigraphy for staging of primary tumors and detection of metastases and recurrences in the long-term follow-up. A stable ${ }^{99 m}$ Tc-labeled Y2-selective analog suitable for this purpose was recently synthesized. ${ }^{38}$ Owing to the heterogeneity of the receptor subtypes in sex cordstromal tumors, an analog with high affinity to both Y1 and Y2 would, however, be more efficient. Ovarian adenocarcinomas respond to anthracyclines, but their use is limited by their cardiotoxicity; ${ }^{35,39,40}$ this side effect might be significantly reduced by receptor-targeted administration. A Y1selective NPY analog coupled to the anthracycline daunorubicin, shown to be cytotoxic and to reduce growth of a Y1-expressing neuroblastoma cell line, ${ }^{41}$ may therefore be evaluated for targeted chemotherapy of Y1-expressing ovarian tumors. Malignant sex cord-stromal tumors have a restricted sensitivity to chemotherapeutic agents; ${ }^{37}$ radiolabeled NPY analogs may possibly be useful for targeted radiotherapy of these tumors. ${ }^{4}$ Their advantage would lie in the reduction of side effects related to conventional radiotherapy of tumors in the peritoneal cavity. ${ }^{17}$ It should also be mentioned that not only tumor cells but also intratumoral vessels expressing NPY receptors may be potential targets for directed radiotherapy.

The significance of nonradioactive NPY or NPY analogs as direct inhibitors of tumor cell growth remains to be established for the in vivo use in humans. It was shown previously in other tumor cell types in culture that NPY can modestly affect tumor growth. ${ }^{6}$ In order to evaluate the functionality of NPY receptors in ovarian cancer, we have performed preliminary studies with various ovarian cancer cell lines including NIH:OVCAR-3, EFO-27, and SK-OV-3. Unfortunately, none of these commercially available ovarian tumor cell lines were expressing NPY receptors to a level permitting functional investigations, making these cell lines of little value as model system. Convincing evidence of a growth control of ovarian cancers through functional NPY receptors may therefore be difficult to provide. For the time being, the main clinical application of the reported data will be to take advantage of NPY-binding sites and perform NPY receptor scintigraphy and radiotherapy. 
Peptide hormone receptors other than NPY receptors are expressed in ovarian neoplasms. Vasoactive intestinal peptide receptors were found in high density and homogeneity in $83 \%,{ }^{14}$ cholecystokinin-B in $14 \%,{ }^{15}$ and different somatostatin receptor subtypes in $19-54 \%{ }^{13}$ of ovarian adenocarcinomas. Most interestingly, however, cholecystokinin-B receptors are present in $100 \%$ of sex cord-stromal tumors. ${ }^{15}$ The extremely high incidence of NPY and cholecystokinin-B receptors in GCT and SLCT is remarkable and intriguing with respect to the possible pathophysiological role of these peptides. Furthermore, the observation of multiple peptide receptor expression may lead to the application of a cocktail of radioligands for a more efficient in vivo receptor targeting of ovarian neoplasms.

\section{Acknowledgement}

We thank Boehringer (Ingelheim, Germany) for the gift of BIBP 3226 and BIIE 0246, and Professor A Beck-Sickinger (Leipzig, Germany) for the gift of the Y5-selective analog $\left[\mathrm{Ala}^{31}, \mathrm{Aib}^{32}\right]$-hNPY. We also thank Dr Ricardo Lloyd of the Department of Laboratory Medicine and Pathology (Mayo Clinic, Rochester, USA), for the generous gift of the majority of the sex cord-stromal ovarian tumors in the present study, as well as Dr Jan-Olaf Gebbers of the Institute of Pathology (Kantonsspital, Luzern, Switzerland), for other selected tumor samples.

\section{References}

1 Reubi JC. Regulatory peptide receptors as molecular targets for cancer diagnosis and therapy. Q J Nucl Med 1997;41:63-70.

2 Kwekkeboom DJ, Krenning EP, de Jong M. Peptide receptor imaging and therapy. J Nucl Med 2000;41:1704-1713.

3 Krenning EP, Kwekkeboom DJ, Pauwels S, et al. Somatostatin Receptor Scintigraphy. Raven Press: New York, 1995, pp 1-50.

4 Waldherr C, Pless M, Maecke HR, et al. Tumor response and clinical benefit in neuroendocrine tumors after $7.4 \mathrm{GBq}$ (90)Y-DOTATOC. J Nucl Med 2002;43:610-616.

5 Lamberts SWJ, Krenning EP, Reubi JC. The role of somatostatin and its analogs in the diagnosis and treatment of tumors. Endocr Rev 1991;12:450-482.

6 Reubi JC, Gugger M, Waser B, et al. Y1-mediated effect of neuropeptide $\mathrm{Y}$ in cancer: breast carcinomas as targets. Cancer Res 2001;61:4636-4641.

7 Reubi JC, Gugger M, Waser B. Coexpressed peptide receptors in breast cancers as molecular basis for in vivo multireceptor tumor targeting. Eur J Nucl Med 2002;29:855-862.

8 Michel MC, Beck-Sickinger A, Cox H, et al. XVI International union of pharmacology recommendations for the nomenclature of neuropeptide Y, peptide YY, and pancreatic polypeptide receptors. Pharmacol Rev 1998;50:143-150.
9 Gehlert DR. Subtypes of receptors for neuropeptide Y: implications for the targeting of therapeutics. Life Sci 1994;55:551-562.

10 Jain MR, Pu S, Kalra PS, et al. Evidence that stimulation of two modalities of pituitary luteinizing hormone release in ovarian steroid-primed ovariectomized rats may involve neuropeptide Y Y1 and Y4 receptors. Endocrinology 1999;140:5171-5177.

11 McDonald JK. Role of neuropeptide Y in reproductive function. Ann NY Acad Sci 1990;611:258-272.

12 Raposinho PD, Broqua P, Pierroz DD, et al. Evidence that the inhibition of luteinizing hormone secretion exerted by central administration of neuropeptide $\mathrm{Y}$ (NPY) in the rat is predominantly mediated by the NPY-Y5 receptor subtype. Endocrinology 1999;140: 4046-4055.

13 Hall GH, Turnbull LW, Richmond I, et al. Localisation of somatostatin and somatostatin receptors in benign and malignant ovarian tumours. $\mathrm{Br} \mathrm{J}$ Cancer 2002;87:86-90.

14 Reubi JC. In vitro identification of vasoactive intestinal peptide receptors in human tumors: implications for tumor imaging. J Nucl Med 1995;36:1846-1853.

15 Reubi JC, Schaer JC, Waser B. Cholecystokinin(CCK)-A and CCK-B/gastrin receptors in human tumors. Cancer Res 1997;57:1377-1386.

16 Nguyen HN, Averette HE, Hoskins W, et al. National survey of ovarian carcinoma. VI. Critical assessment of current International Federation of Gynecology and Obstetrics staging system. Cancer 1993;72:3007-3011.

17 Segal R, DePetrillo AD, Thomas G. Clinical review of adult granulosa cell tumors of the ovary. Gynecol Oncol 1995;56:338-344.

18 WHO. In: Scully R (ed), World Health Organization International Histological Classification of Tumors. Histological Typing of Ovarian Tumors, 2nd edn. Springer: Berlin, Heidelberg, New York, 1999.

19 Aicher SA, Springston M, Berger SB, et al. Receptorselective analogs demonstrate NPY/PYY receptor heterogeneity in rat brain. Neurosci Lett 1991;130: 32-36.

20 Dumont Y, Cadieux A, Doods H, et al. BIIE0246, a potent and highly selective non-peptide neuropeptide $\mathrm{Y} \mathrm{Y}_{2}$ receptor antagonist. Br J Pharmacol 2000;129: 1075-1088.

21 Rudolf K, Eberlein W, Engel W, et al. The first highly potent and selective non-peptide neuropeptide $\mathrm{Y} \mathrm{Y}_{1}$ receptor antagonist: BIBP3226. Eur J Pharmacol 1994;271:R11-R13.

22 Pelkey TJ, Frierson Jr HF, Mills SE, et al. The diagnostic utility of inhibin staining in ovarian neoplasms. Int J Gynecol Pathol 1998;17:97-105.

23 Riopel MA, Perlman EJ, Seidman JD, et al. Inhibin and epithelial membrane antigen immunohistochemistry assist in the diagnosis of sex cord-stromal tumors and provide clues to the histogenesis of hypercalcemic small cell carcinomas. Int $\mathrm{J}$ Gynecol Pathol 1998;17:46-53.

24 Risbridger GP, Schmitt JF, Robertson DM. Activins and inhibins in endocrine and other tumors. Endocr Rev 2001;22:836-858.

25 Cabrele C, Langer M, Bader R, et al. The first selective agonist for the neuropeptide YY5 receptor increases food intake in rats. J Biol Chem 2000;275:36043-36048.

26 Matsuda H, Brumovsky PR, Kopp J, et al. Distribution of neuropeptide Y Y1 receptors in rodent peripheral tissues. J Comp Neurol 2002;449:390-404. 
27 Wharton J, Gordon L, Byrne J, et al. Expression of the human neuropeptide tyrosine Y1 receptor. Proc Natl Acad Sci USA 1993;90:687-691.

28 Russel P, Robboy SJ, Anderson MC. The ovaries: normal appearances and non-neoplastic conditions, In: Robboy SJ, Anderson MC, Russel P (eds). Pathology of the Female Reproductive Tract. Churchill Livingstone: London, 2002, pp 475-526.

29 Jorgensen JC, Sheikh SP, Forman A, et al. Neuropeptide $\mathrm{Y}$ in the human female genital tract: localization and biological action. Am J Physiol 1989;257: E220-E227.

30 Jorgensen JC. Interaction between norepinephrine, NPY and VIP in the ovarian artery. Peptides 1991;12:831-837.

31 Barreca A, Valli B, Cesarone A, et al. Effects of the neuropeptide $\mathrm{Y}$ on estradiol and progesterone secretion by human granulosa cells in culture. Fertil Steril 1998;70:320-325.

32 Kurman RJ, Goebelsmann U, Taylor CR. Steroid localization in granulosa-theca tumors of the ovary. Cancer 1979;43:2377-2384.

33 Gurusinghe CJ, Healy DL, Jobling T, et al. Inhibin and activin are demonstrable by immunohistochemistry in ovarian tumor tissue. Gynecol Oncol 1995;57:27-32.

$34 \mathrm{NIH}$. NIH consensus conference: ovarian cancer. Screening, treatment, and follow-up. NIH consensus development panel on ovarian cancer. JAMA 1995;273:491-497.

35 Hernadi Z, Juhasz B, Poka R, et al. Randomised trial comparing combinations of cyclophosphamide and cisplatin without or with doxorubicin or 4'-epidoxorubicin in the treatment of advanced ovarian cancer. Int J Gynaecol Obstet 1988;27:199-204.

36 Young RH, Scully RE. Ovarian Sertoli-Leydig cell tumors. A clinicopathological analysis of 207 cases. Am J Surg Pathol 1985;9:543-569.

37 Gershenson DM, Morris M, Burke TW, et al. Treatment of poor-prognosis sex cord-stromal tumors of the ovary with the combination of bleomycin, etoposide, and cisplatin. Obstet Gynecol 1996;87:527-531.

38 Langer M, La Bella R, Garcia-Garayoa E, et al. 99mTclabeled neuropeptide y analogues as potential tumor imaging agents. Bioconjug Chem 2001;12:1028-1034.

39 Chiara S, Merlini L, Campora E, et al. Cisplatin-based chemotherapy in recurrent or high risk ovarian granulosa-cell tumor patients. Eur J Gynaecol Oncol 1993;14:314-317.

40 Shimizu Y, Nagata H, Kikuchi Y, et al. Cytotoxic agents active against mucinous adenocarcinoma of the ovary. Oncol Rep 1998;5:99-101.

41 Langer M, Kratz F, Rothen-Rutishauser B, et al. Novel peptide conjugates for tumor-specific chemotherapy. J Med Chem 2001;44:1341-1348. 